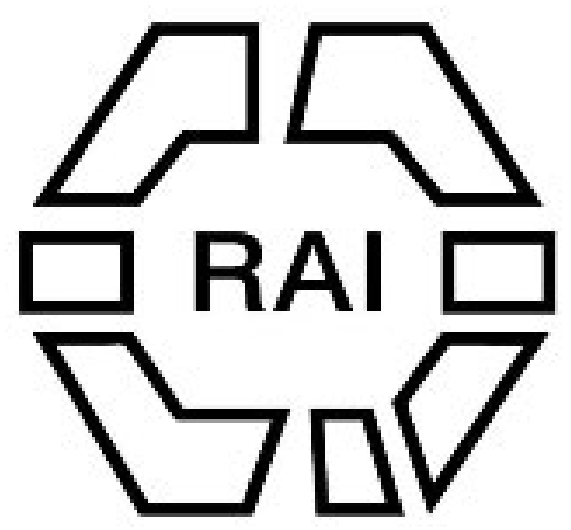

Among the Wild Ngoni by W. A. Elmslie

Review by: F. C. S.

The Tournal of the Anthropological Institute of Great Britain and Ireland, Vol. 29, No. 1/2 (1899), pp. 191-192

Published by: Royal Anthropological Institute of Great Britain and Ireland

Stable URL: http://www.jstor.org/stable/2842602

Accessed: 15/06/2014 20:53

Your use of the JSTOR archive indicates your acceptance of the Terms \& Conditions of Use, available at http://www.jstor.org/page/info/about/policies/terms.jsp

JSTOR is a not-for-profit service that helps scholars, researchers, and students discover, use, and build upon a wide range of content in a trusted digital archive. We use information technology and tools to increase productivity and facilitate new forms of scholarship. For more information about JSTOR, please contact support@jstor.org. 
The Negritos. By A. B. Meyer, M.D. Dresden: Stengel and Co., 1899.

This is a translation by Miss C. S. Fox of two chapters from the author's work on the Negritos of the Philippine Islands. It is a review of the chief authorities on the existence of the Negrito race in the Philippine Islands, Borneo, Java, Sumatra, the Andamans and Nicobar, India and Australia, and New Guinea. The general result is to show that the existing evidence is incomplete and unsatisfactory, and that much further inquiry is needed before the question of the ethnology of this part of the world can be finally settled.

W. Crooke.

The Temple of Mut in Asher. An account of the excavations of the temple and of the religious representations and objects found therein as illustrating the history of Egypt and the main religious ideas of the Egyptians. By Miss Margaret Benson and Miss Janet Gourlay. London: John Murray, 1899.

This is the result of three years' diggings in the Temple of Mat, near Karnak, undertaken by these two enterprising and energetic ladies, who may be said to be the first women who have had permission granted them by the Egyptian Government to make excavations on any site in Egypt, for which they are deserving of all praise as they appear to have conducted it very carefully.

In the course of the work they discovered some highly interesting statues and monuments, many very fragmentary. The most notable are those of Sen-Mut, the architect of the Temple of Dêr el Bahari, favourite and Chief Steward of the celebrated Queen Hatshepsut of the XVIIIth Dynasty; the statue of Mentu-em-hat, and the remarkable heads of the woman of the Saitic period and the so-called Philistine.

The book is highly interesting and well got up, illustrated with photographs and plans. It is decidedly worth reading, although the shortness of the actual description of excavations is somewhat disappointing. The work contains several chapters upon the religion and history of Egypt during the period the Temple of Mut was flourishing, and is supplemented by a chapter by Mr. Percy Newberry, describing and translating the inscriptions from the monnments discovered.

F. G. H. P.

The Philippine Islands; a political, geographical, ethnographical, social and commercial history of the Philippine Archipelago and its political dependencies, embracing the whole period of Spanish Rule. By John Foreman, F.R.G.S. 2nd Edition. London: Sampson Low, Marston and Co., 1899.

This is a most elaborate account of a portion of the world which recent events render particularly interesting. It is well illustrated and supplied with an excellent map. It will long remain the standard account of the Spanish Dependencies in Eastern Asia. Mr. Foreman's account of the native races is disappointing, and in particular he has done little to throw light on the Negrito peoples.

W. Crooke.

Among the Wild NGoni. By Dr. W. A. Elmslie. Edinburgh and London : Oliphant Anderson and Ferrier, 1899.

This book serves a double purpose; it gives an account of the founding of several stations of the Livingstonia Mission in the northern part of British Central Africa, and at the same time briefly describes the natives themselves, their customs and 
beliefs. The book is the more valuable from the length of time the author has worked in the district. Among the sections of greatest interest to the anthropologist is perhaps the history of the Ngoni pieced together from various native narratives. The author traces the reflux wave of the Zulu-Xosa group of Abantu from the borders of Natal. Driven before the victorious arms of Chaka they retired northward in several streams at short intervals of time, and founded warlike communities on the Zulu model, such as the Matabele in Mashonaland, the Ngoni to the west, and the Magwangwara to the east of Lake Nyasa and the Watata, who reached as far as the Victoria Nyanza.

A fuller account than had previously been published in popular form is given of the native war dances, the itshanusi or medicine men, and the poison ordeal by drinking muave. It is to be hoped Dr. Elmslie will at some other time supply a fuller record of Ngoni customs, beliefs, and medical practice than was practicable in the limits of this book.

F. C. S.

\section{Vocabulary of the Gualluma tribe inhabiting the plains between the Yule and Fortescue Rivers, North-West Australia.}

The following vocabulary, prepared by Mr. E. Clement, of an Australian tribe hardly if at all known from a philological point of view, is interesting. It may be hoped that before this language becomes extinct, the rules of inflexions and syntax, hardly touched on in the present paper, will be worked out. In the meantime it is to be noticed that words related to those of other Australian tribes at vast distances are to be found in the present vocabulary, connecting the Gualluma with other members of the Australian family of languages.

E. B. TyLoR.

Numerals :-

1, Cünjēriě (" $\mathrm{j}$ " is pronounced as in English "jam").

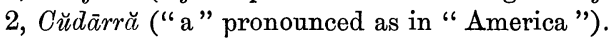

3, Bürgŏ (" 11 " pronounced as in "full ").

4, Cudarra-cudarra.

5, Cudarra-cudarra-cunjerie.

6, Māngā (plenty) or Mãrrŭ (plenty).

7 ,

8 , 9 , etc.

Manga or Marru ("u" pronounced as "oo" in "cool ").

On the Upper Sherlock River I frequently heard burgo-burgo for 6, but not elsewhere.

Comparison :-

The comparison is formed by placing mahma, more, before the adjective as :

$v \bar{\imath} b \bar{\imath}$, good.

mahma waba, better.

cŭngēră, high ("g" pronounced as in English "gate").

mahma cungera, higher.

There is no superlative.

Genders, none.

Cases, none. 